to five years, are used to finance a wide variety of conservation projects, such as: land purchase for conservation projects, environmental education, deforestation control, reforestation in reserves or watershed-protection areas, research, and projects to plan, manage, and protect, National Parks and Forest Reserves. The entire programme is managed by The National Park Foundation under the supervision of the Ministry of Natural Resources (Umaña, 1987). The international community, recognizing the combination of biological diversity, political support, and favourable research conditions involved, has enthusiastically responded to this programme. The original level of US $\$ 5.4$ millions was overtopped in June 1989 , when the programme brought US $\$ 35$ millions to Costa Rica while relieving it of US $\$ 75$ millions in foreign debt.

\section{ACKNOWLEDGEMENTS}

The Author wishes to express his profound gratitude to the Fundación Neotrópica and The National Conservation Strategy for Sustainable Development of Costa Rica (ECODES), and to the Costa Rican Ministry of Natural Resources, for providing the information without which this paper could not have been written.

\section{REFERENCES}

Hartshorn, G. (Ed.) (1982). Perfil Ambiental de Costa Rica Tropical Science Center, San José, Costa Rica: xiii + 151 pp.

IUCN (1980). World Conservation Strategy. International Union for Conservation of Nature and Natural Resources, Gland, Switzerland: vii + 54 pp., illustr.

IUCN (1987). Costa Rica's National Conservation Strategy: Leading the way. (Special Report on Central America.)
International Union for Conservation of Nature Bulletin, 18(10-12), pp. 4-5.

LEORNARD, J. (1987). Natural Resources and Economic Development in Central America: A Regional Environmental Profile. Transaction Books, New Brunswick, NJ, USA: xxii + 279 pp., illustr.

MARCLINDENBERG, M. (1988). Central America's elusive economic recovery. World Development, 16(2), pp. 237-54.

Quesada, C. (1988). La Forja de ECODES. Ministerio de Recursos Naturales Energía y Minas. Estrategia Nacional de Conservación Para el Desarrollo Sostenido, San José, Costa Rica: 18 pp.

Ramirez, S.A. \& MAldonado, U.T. (Eds) (1988). Desarrollo Socioeconómico y el Ambiente Natural de Costa Rica: Situación Actual y Perspectivas. Fundación Neotrópica, Editorial Heliconia, San José, Costa Rica: 160 pp., illustr.

Umaña, A. (1987). Costa Rica Swaps Debt for Trees. The Wall Street Journal, March 6, 1987, p. 31. Washington, USA.

WORLD RESOURCES INSTITUTE (1988). World Resources 1988-89. A Report by the World Resources Institute and the International Institute for Environmental Development, Basic Books Inc., New York, NY, USA: vii + 372 pp., illustr.

\section{Julio C. Calvo}

Departemento de Ingenieria Forestal Instituto Tecnologico de Costa Rica Aptdo. 159-7050 Cartago Costa Rica.

Currently:

College of Forest Resources

Box 8002

North Carolina State University

Raleigh

North Carolina 27695, USA.

\title{
WWF's Mission - Towards Creating a Sustainable World
}

Concern for the world's fragile ecosystems has lately been dominating newspaper headlines, broadcast media, discussion agendas of world leaders, and public opinion around the globe. Thus in Thailand last year, after an avalanche of logs and mud had swept down and denuded hillsides, killing more than 450 people and destroying thousands of homes, the country's Prime Minister declared a nationwide logging ban. Neighbouring Laos and Vietnam have also declared a ban on the export of raw logs, and the latter country is planting a record 160,000 ha of trees each year, the work being undertaken largely by schoolchildren. In Guatemala, an ambitious scheme to plant 10 million trees during this decade is under way, while the Australian Government has drawn up plans to plant one thousand million trees during the $\mathrm{AD}$ 1990s.

Given the recent growth in public concern, it is no wonder that during the last two annual Summit meetings of the Group of Seven - the world's richest industrialized nations - discussion on impending climate change, excessive deforestation, and stratospheric ozone depletion, consumed a large part of the sessions. WWF Gold Medallist for 1989 Lester R. Brown, who is Editor and Co-author of the internationally recognized annual State of the World report*, says that only a monumental effort could reverse the deterioration of the planet. Speaking at WWF's annual conference in Montreux, Switzerland at which representatives of all of WWF's 28 National Organizations were putting the final touches to the organization's new mission and strategy - Mr Brown expanded on his vision of a 'sustainable world'.
A recent poll showed that the proportion of US citizens endorsing environmental protection - regardless of costs - has risen from $45 \%$ in 1981 to $80 \%$ today. Public concern in European countries is similar. For example, in postcardperfect Switzerland, where lakes and forests are dying, the population now says the number-one issue which the Government must tackle is environmental protection.

\section{New Mission and Strategy}

Responding to this growth in interest and widespread concern, WWF has decided on a new mission for the 1990s. As decided and declared at its 1990 annual conference in Montreux (see above), the 'sustainable world' which they visualize would be both traditional and extremely modern. It would be a world which used the latest environmentally-friendly technology - a world which is not beyond our reach, if only we are willing to meet the challenge of change and make the sacrifices that will be necessary for planetary survival. Recognizing on one hand the need for change to stop the 'tidal wave' of environmental destruction that is looming over us all, and, on the other, the opportunities presented by the burgeoning thrust of environmental awareness practically the world over, WWF embarked on a planning exercise to develop a new strategy.

* See Professor W. Robert Stanton's review of the latest (1990) one in our Summer issue (Environmental Conservation, 17(2), p. 191, 1990). — Ed. 
In its early years, WWF had acted mainly as a fundraising and then 'fire brigade organization', reacting to environmental crises and urgent conservation needs. WWF is now able to look to the future and be far more pro-active than formerly. Its budget has trebled from some SF 80 millions (c. US \$64 millions) in 1985 to SF 250 millions (c. US $\$ 198$ millions) today, and its regular supporters have doubled in number over the same period to reach a figure of almost four millions.

\section{Three Major Goals}

The scope and complexity of WWF's activities have similarly increased, and it is now developing three specific programmes to address its major goals: 1 ) biological diversity, 2) ensuring that use of renewable natural resources is sustainable, and 3) reducing wasteful consumption and pollution; already it has reorganized its management structure at WWF headquarters in Switzerland accordingly.

To help in the attainment of those goals, three additional divisions have been created at WWF headquarters: Conservation Policy, Ethics and Education, and Institutional Development. To back the mission and new strategy, WWF will, over the next five years, spend US $\$ 150$ millions on field projects in Africa, Asia, and Latin America. Another US $\$ 120$ millions will be spent on education, conservation policy, lobbying, institutional support, and heightening public awareness.

Essential to the success of WWF's strategy will be its newly-formed regional teams which will oversee activities in focal conservation areas. These regional teams will include suitably-qualified scientists, financial managers, and experienced administrators. Help will be provided by representatives from the Conservation Policy, Ethics and Education, Institutional Development, Communications, and Fund-raising, Divisions.

\section{Local Participation}

Local participation has become a standard-bearer in conservation project description, but good examples are needed to show that the involvement of local people is much more than empty jargon. It is not practicable to get people to participate actively in, and benefit from, field programmes unless such programmes are designed locally and tackled with a long-term view. WWF has therefore started to move its programme development and implementation closer to the field, into the countries concerned.

WWF will, for example, continue to help to develop and to finance endeavours such as the Yanesha project in Peru, where a unique experiment in ecologically sensitive forestry, the first in South America managed by Amerindians, is reaping social, economic, and environmental, benefits for the indigenous people who run it. Last year, the Yanesha Forestry Cooperative exported its first shipment of timber from sustainably managed forests to the US and the UK.

\section{Conservation Policy}

WWF will continue to encourage members of the International Tropical Timber Organization (ITTO) to develop similar, sustainably-managed forest projects. In addition, WWF will step up its efforts to lobby effectively for conservation measures at international fora such as the ITTO, Ramsar (the international treaty for wetland protection), the International Whaling Commission, the European Economic Community, and CITES (the Convention on International Trade in Endangered Species of Wild Fauna and Flora).

It is hoped that these and other projects will be as exemplary as the successful initiative taken by WWF and the Asociacion de Defensa del Pirineo Aragones (ADEPA) to force an end to toxic-waste dumping in the Pyrenean mountains of Spain. After persistent urging by WWF and ADEPA to the Spanish Government, and tough lobbying at the EEC, a factory which had been producing the highly-toxic pesticide Lindane, and had dumped 100,000 tonnes of toxic wastes into the countryside and local drinking-water, has been shut down. WWF and ADEPA are now pressing for a clean-up of the site.

\section{Ethics and Education}

During the coming years, WWF will also expand its work in education and its conservation and religion network to embrace the broad subject of conservation ethics. The new Ethics and Education Department will develop and coordinate WWF's international activities in ethics, religion, and education, including cooperation with scouts, guides, and the Duke of Edinburgh's Award Scheme.

Projects such as WWF's education programme in Madagascar will be further encouraged. Developed by the Malagasy people and using local materials with the country's needs and problems in mind, the education programme has been introduced in 28 of Madagascar's 122 school districts. By 1992 it should reach out to the entire country.

\section{Managing the Mission}

Among the first tasks of the newly-formed Institutional Development Division will be the evaluation of local needs in order to assist and support WWF National Organizations, thereby boosting the strength of the WWF family worldwide. For instance, WWF will continue to provide technical and financial support to governmental institutions and to NGOs such as Costa Rica's Tropical Agricultural Research and Training Centre which is a focal point of pertinent activity for seven countries in Central America. WWF will also support the establishment of new NGOs in developing countries where WWF is particularly active and where there is a demonstrable need.

A strong world-wide NGO movement is a key factor in achieving the concerted, global action which is required to address the innumerable problems involving the natural environment. WWF is committed to supporting and building up local institutions as an important factor in achieving its mission.

In Europe, WWF is reorganizing its programme to support critically-needed conservation efforts to counter transboundary pollution and other pressing environmental problems. The expansion of the programme began earlier this year with the establishment of WWF's first Eastern European office in Potsdam, Germany, and the recent appointment of an Eastern European specialist.

\section{A Financial Watchdog and Fund-raising}

WWF is to employ a new watchdog - a financial auditor in the Administration and Finance Division with direct access to the Management Executive and the Honorary Treasurer. This in-house auditor, who will also visit field projects, will liaise closely with financial 
managers in WWF's regional teams - to ensure that accountability on the use of funds is provided regularly by WWF to its donor public.

While the bulk of WWF money may still be raised through appeals to the public's generosity in the form of subscriptions, donations, and legacies, additional support will be sought from commerce and industry, from bilateral and multilateral aid agencies, and through licensing WWF's Panda symbol. Every cent or penny that is donated to WWF International for conservation will continue to be used for that purpose, fund-raising and basic administration costs being already covered by income from capital funds such as the 1001 Club, A Nature Trust, and various commercial activities.

\section{Communications}

Under WWF's new strategy, communication of information will be a major support-tool in all phases of accomplishing its mission, including building environmental awareness and increasing understanding of WWF activities. One of the major areas of growth at the international headquarters, this Division will step up its experti- se in advertising and public relations, establish a broadcasting unit, and position itself as a media centre servicing the WWF family on a rapid-fire and accurate basis.

This unit will increase public awareness at all levels of society, ranging from the village centre (where, for instance, tribal and local people glean information) to major cities of the world (where key decisions are made by government leaders). Through various media and personal contacts, WWF will transmit its message to decisionmakers, major organizations, and the general public.

WWF's revised mission and new strategy, which are the result of a year of intensive consultation within the world-wide WWF family and with outsiders, now guide the organization and its growing number of regular supporters - almost 4 millions - around the globe on a critically important course. The mission must succeed.

ElZABETH KeMF, Editor
WWF News
World Conservation Centre
Avenue du Mont-Blanc
1196 Gland, Switzerland.

\section{The Swiss National Climate Programme (ProClim): Objectives and Prospects}

\section{Introduction}

ProClim (Programme Climatologique), the Swiss National Climate Programme, was set up in 1987 on the initiative of the Swiss Academy of Sciences, following the recognition that Switzerland should participate in global efforts in climate research as a result of world-wide preoccupation with climate change. Indeed, as a highlydeveloped country, Switzerland contributes its share, albeit small, to 'greenhouse' gas concentrations in the atmosphere, and therefore has a responsibility to provide scientific and policy responses to the problem of global warming.

The objectives of the Swiss National Climate Programme are multidisciplinary of necessity, as may be seen from this overview of its scientific objectives. Furthermore, recognizing the fact that information is often poorly broadcast to the general public, a major effort is being made to transfer research results in a comprehensible manner to the press and general public. Clear public information is essential if one is to raise the awareness of the nonscientific community, the press, and politicians, to the acute consequences of global climate change and the urgent steps which need to be taken forthwith to limit global warming and concomitant changes. ProClim publishes an information brochure (ProClim News) on a regular basis, and has edited a book for the general public on the subject of global change (Schotterer \& Andermatt, Climate-Our Future?, Bern, 1990).

Advanced education, through short courses on very specific climate topics, is a further aim of the Swiss National Climate Programme, and yet another is the organization of workshops and conferences. Regular events of this nature in Switzerland would allow our small country to play an important role in the international climate community, which has come to occupy a particularly prominent position of late with active renewal of the debate on global climatic change.

\section{Fourfold Scientific Objectives of ProClim}

1. Process Understanding:- If we are to gain insight into the possible future trends of global change, it is essential to understand the mechanisms of the climate system itself. Of special interest to Switzerland are the links between small- or regional-scale atmospheric processes and global climate. For example, mountain barriers such as the Alps have a significant dynamic effect on the general circulation of the atmosphere, but are poorly represented in General Circulation Models (GCMs). The study of the dynamic effects of mountains, land-surface processes, cloud-radiation interactions, and the Earth's radiation budget, either through observation or through detailed numerical model studies, will ultimately lead to an improved understanding of climatically relevant small-scale processes. As a consequence, these processes could then be more adequately represented in GCMs, leading to improved predictability of climate and its evolution.

Detailed model studies can also be envisaged to investigate the impacts of climate change on The Biosphere (such as ecological sensitivity of the Alpine world) and the included hydrosphere (such as hydrological balance for water-supply and energy resources) and cryosphere (such as glacier and snowline advance or retreat). The various interactions and feedbacks between the general free atmosphere and what may be called the 'central biosphere', including The Biosphere's component hydrosphere and cryosphere, are summarized in Fig. 1.

2. Past Climate Reconstruction:- The use of so-called climate archives as an indicator of climates of the past and their natural fluctuations, is one area where Swiss science has excelled. Climatic indicators can be found in many types of records, such as glacial cores, marine and lake sediments, coral reefs, tree rings, and dust deposits in caves. The analysis of stratified sediments, gas content 